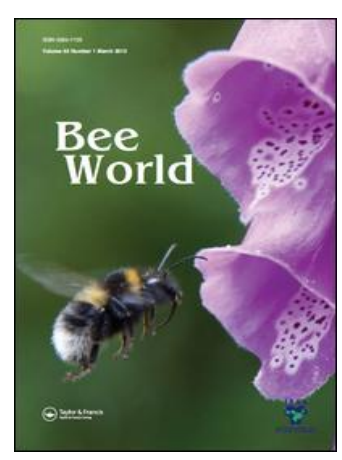

Bee World

ISSN: 0005-772X (Print) (Online) Journal homepage: http://www.tandfonline.com/loi/tbee20

\title{
Humours of Beedom-XIV
}

\section{E. F. Hemming}

To cite this article: E. F. Hemming (1922) Humours of Beedom-XIV, Bee World, 4:2, 46-46, DOI: 10.1080/0005772X.1922.11095370

To link to this article: http://dx.doi.org/10.1080/0005772X.1922.11095370

\section{曲 Published online: 31 Jul 2015.}

Submit your article to this journal ㄴ

Џll Article views: 1

Q View related articles ¿ 
at the same time have stamped the packages according to class and $\operatorname{grade}:-$

...........packages Special Grade...........honey.

...........packages A or Prime Grade............honey.

............packages $\mathbf{B}$ or Good Grade..................

Total number of packages : Brand:

Producer's No.

\section{PURE HONEY.}

\begin{tabular}{|c|c|c|c|c|c|}
\hline- & 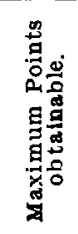 & 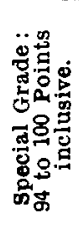 & 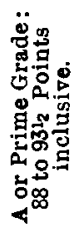 & 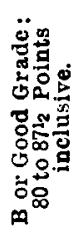 & 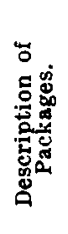 \\
\hline \begin{tabular}{lr} 
Flavour & $\ldots$ \\
Colour ... & $\ldots$ \\
Condition & $\ldots$ \\
Grain or texture \\
Freedom from \\
\multicolumn{2}{c}{ scum and froth }
\end{tabular} & $\begin{array}{l}50 \\
10 \\
15 \\
15\end{array}$ & & & & \\
\hline & 100 & & & & \\
\hline $\begin{array}{cc}\text { Total points al- } \\
\text { lotted }\end{array}$ & - & & & & \\
\hline
\end{tabular}

Remarks:

Port:
Date:
, 1922.
F. D. Thomson,

Clerk of the Executive Council.

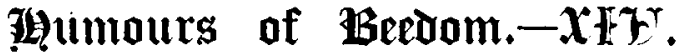

By the Rev. E. F. HEMMING.

A STRIKING JUDGMENT.

"Jutgment is forced upon us by experience."-JoHsson.

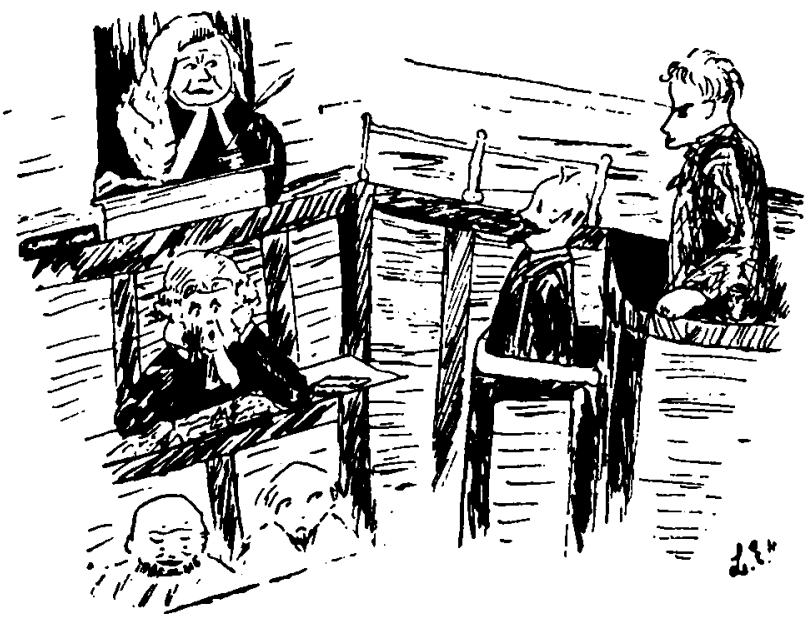

Fig. 20.

The Prosecution: "The charge, my lord. is that the misoners did break into an apiary and stole a stock of bess and 20) lls.s. of honey, some of whirh, with insolent effrontery, they did devour in the presence of the ouener, whom they had previously bound with ropes!"
The Judge: "Discharge the prisoners! I myself recently stole a few hours to devour the 'Bee World' and was held spell-bound!"

With all his long experience, Mr. Isaac Hopkins, a pioneer of modern bee culture, candidly remarked, "The coming of the Bce World gives me more pleasure than all the rest ot my nine bee journals." His judgment is being echoed in both hemispheres.

THE PENALTY OF IGNORANCE.

"Ignorance is a dangerous and spiritual poison, which all men nught rarily to shun."-GREGORY.

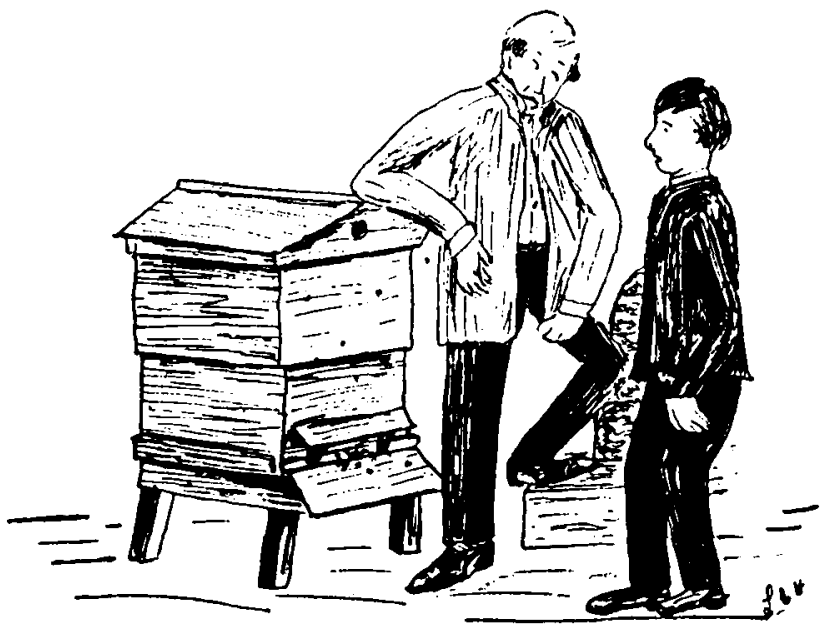

Fig. 21.

Gardener (who keeps a "fow bees," to a new and a somewhat nervous assistant): "Now. Walters, I am going away for the day; what steps will you take if these bees swarm out?"

Waiters: "Steps? Why, long 'uns, Master, long 'uns!"

I once saw a tennis party demoralised because bees from a hive in a garden near by swarmed! How long will it take us to teach the public a few facts on bees and to convince the sceptics that the last thing a swarming bee wants to do is to insert her sting into the flesh of a human?

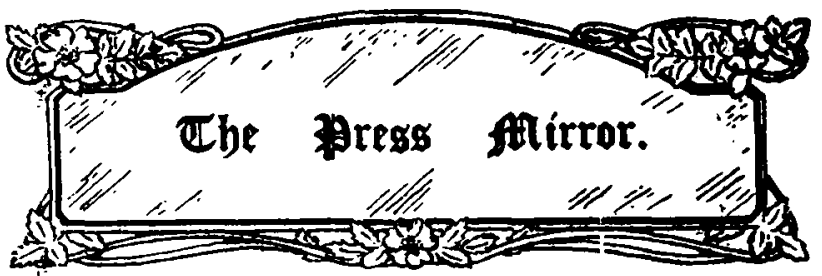

Much has been accomplished; more than people are avare$s_{1}$ gradual has been the advance. How noiseless is the growth of corn! I'atch it night and day for a week, and you will n'ver see it growing; but return after two months and you will. find it all whitening for the harvest. Such, and so imperceptible in the stages of their motion, are the victories of the press.-DF Quincry.

\section{bulletin de la" Eociété dompiculture des alpes= flaritimes.}

Acarine Disease.-The first important act of this newlyformed Ascociation was to petition the French Minister of Agriculture to take steps to prevent the entry into France of 